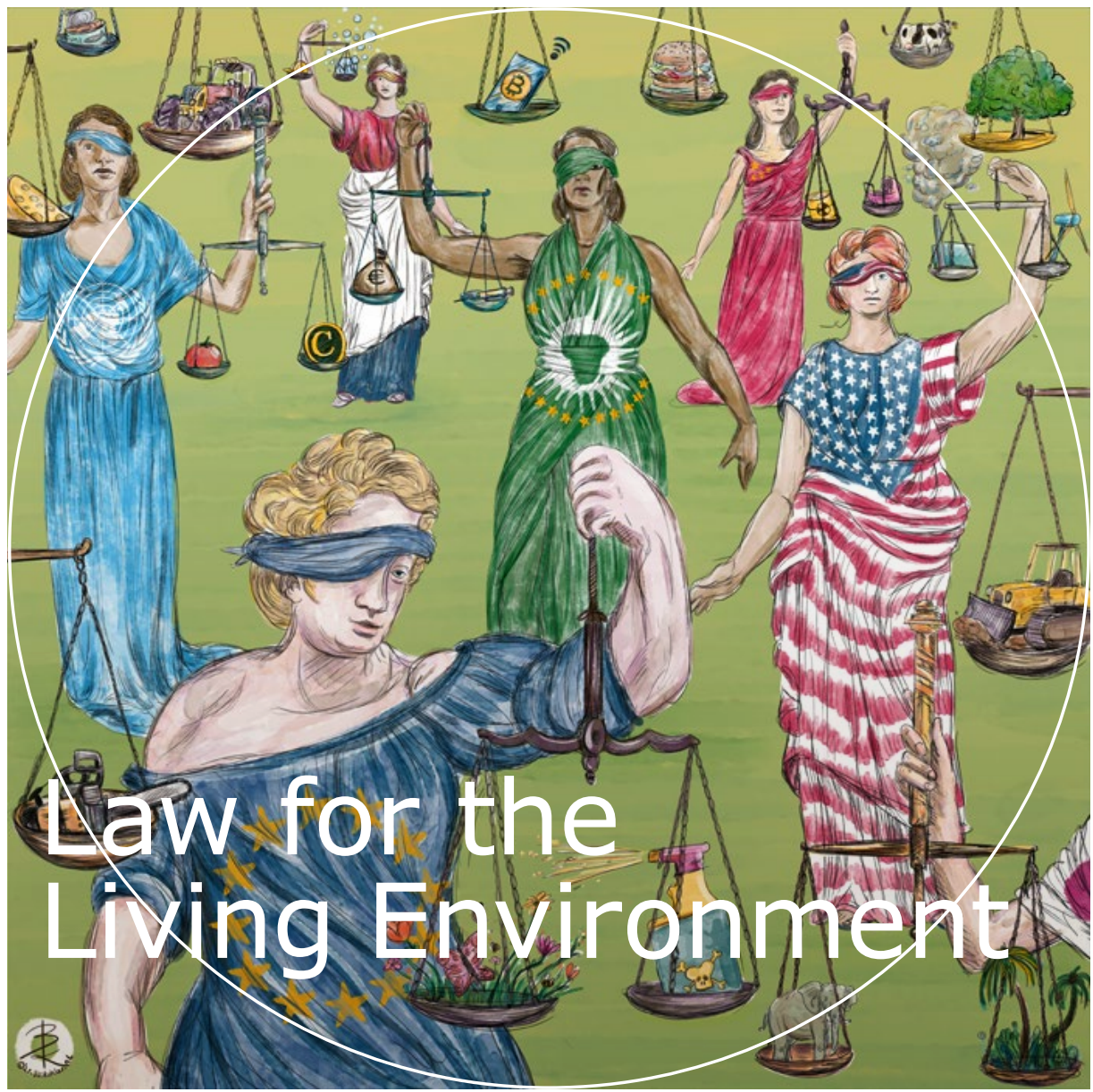

Prof.dr mr. Josephine A.W. van Zeben

Inaugural lecture upon taking up the position of Professor of Law at Wageningen University \& Research on 7 October 2021 



\section{Law for the Living Environment}

Prof.dr mr. Josephine A.W. van Zeben

Inaugural lecture upon taking up the position of Professor of Law at Wageningen University \& Research (WUR) on 7 October 2021 
Illustrations Bas Köhler

DOI https://doi.org/10.18174/555563

ISBN 978-94-6447-001-7

C2021 Prof.dr mr. Josephine A.W. van Zeben; WU. All rights reserved. No parts of this publication may be reproduced by print, photocopy, stored in a retrieval system or transmitted by any means without the prior written permission of the author. 


\section{Law for the Living Environment}

Esteemed Rector Magnificus, dear colleagues, students, family and friends.

\section{Unknown futures}

Two months ago, the International Panel on Climate Change released its most recent report. ${ }^{1}$ The report stressed that unless we take rapid, large-scale and immediate action, limiting average global temperature rise to 1.5 or 2 degrees Celsius will be beyond our reach.

In response to the IPCC report, Mark Blyth - an economist from Brown University - concluded that "there are now only unknown and unfamiliar alternative futures that we can choose from." ${ }^{2}$ This uncertainty constitutes one of the main challenges of climate change policy. When confronted with uncertainty, people assume that "out-of-the-ordinary" events - such as adverse climate events or pandemics - are temporary diversions from the norm, after which a return to "normal" is possible. This may help to explain why the immediate and serious threat of climate change has failed to trigger a durable reconceptualisation of the relationship between humans and their living environment.

Yet, our view of unknown futures need not, and should not, be a negative one. With a "growth mindset", ${ }^{3}$ a situation of permanent uncertainty and change would be met as an opportunity to grow into what we aspire to be, rather than fear to lose who we are. Adopting a "growth mindset" towards the dynamic change of our living environment would therefore allow us to trigger transformative growth, leading to better unknown futures.

As I will discuss today, the law can, and must, play a powerful role in triggering, facilitating and maintaining such a mindset. 


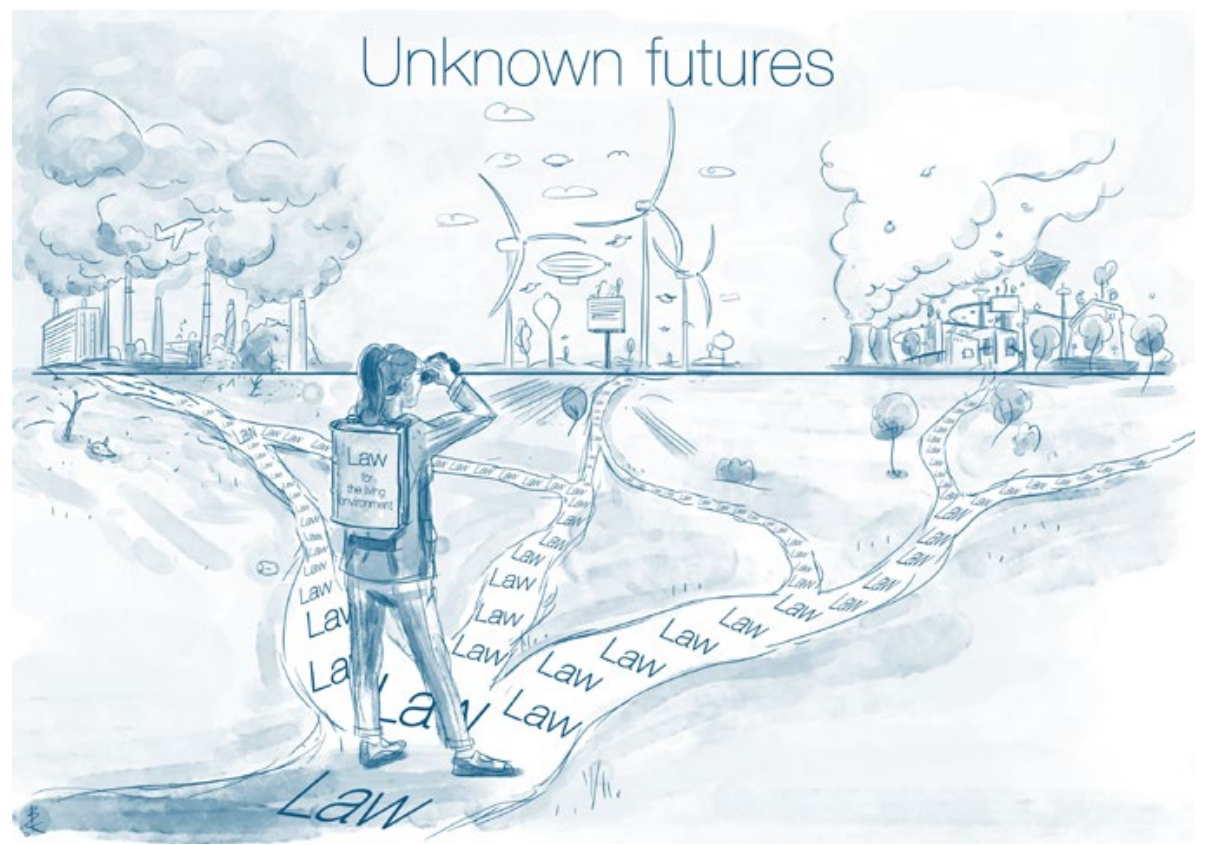

In December 1917, a chair of law was established at Wageningen, though both the chair and the university were yet to adopt their current names. ${ }^{4}$ At the time, the chair was divided between two professors; Professor Heringa, professor of "constitutional law, statistics and Dutch agricultural law"; and, Professor Kielstra, professor of "colonial constitutional and penal law, Indonesian rural economics and Indonesian agricultural law". Much has changed since 1917 - we rightly no longer speak of "colonial" law, and the membership of legal academia has become a lot more diverse.

I will spend most of my time today emphasising other ways in which the world has and will continue to change. Yet, in reading Professor Kielstra's inaugural lecture held on also on October 7, though in 1918 - I was struck by the continued fundamental nature of the questions we both look to answer.

In his lecture, titled "Law and Reality", ${ }^{5}$ Kielstra observed that to many non-lawyers, the law seems quite distant from, and unrelated to, their lived experience. In light of this observation, Kielstra concludes his lecture by addressing his students. Freely translated, Kielstra ends by stating "I pray to be able to show you the relationship between our realities and the law, and in having done so, leaving you better prepared for life." ${ }^{6}$ Kielstra's conclusion is the starting point of my lecture today: law is everywhere and shapes our lived reality in pervasive ways. 


\section{Mandate:}
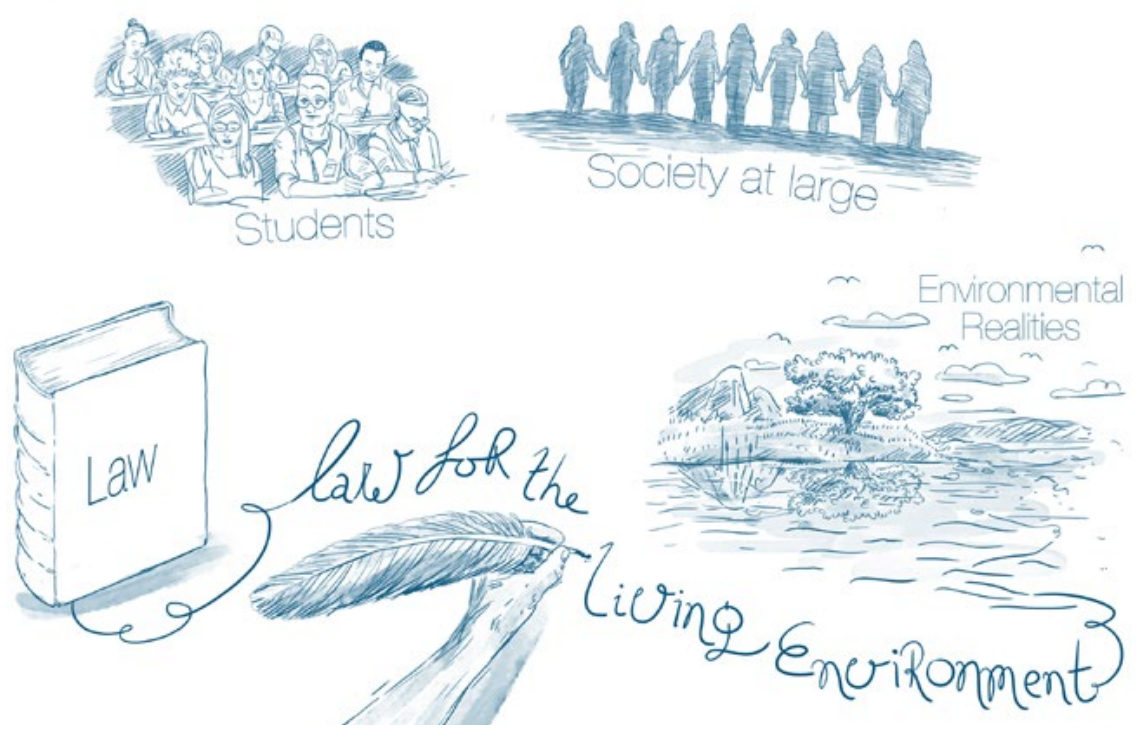

Perhaps influenced by Kielstra's prescient understanding of the impact of law on reality, Wageningen's commitment to providing its students, especially also those in the life sciences, with a legal education to complement their technical understanding of reality has remained unchanged over the past century. This commitment provides a strong and fertile basis for the ambitious mandate and research agenda that the Law Chair Group at Wageningen has adopted.

I understand the mandate of this chair as first and foremost, continuing to draw out the relationships between our environmental realities and the law, so as to better prepare our students, and society at large, for lives in new and unknown normals. In order to do so, the LAW Group at Wageningen must be a place where research related to - what I call - "law for the living environment" provides opportunities for growth under conditions of continuous change and complexity.

In the remainder of this lecture, I will reflect on the legal and practical realities that contextualize and shape this mandate, and on the future that I believe we can grow. First, I will consider the challenges of defining what constitutes "law for the living environment" and how best to understand the role of law in the living environment. As I go, I will discuss two developments that complicate our ability to effectively shape our living environment: complexity and dynamic change. Second, I will 
reflect on how strategies for addressing our living environment must transform as our environment transforms, and on what this means for the role of law and the role of humans. In particular, I will suggest that we do best when we grow legal systems that mirror the complex and dynamically changing environment.

Our best strategy for this is to grow a future that is even more "polycentric" than our past-even more ready to function and to develop from multiple and overlapping starting points.

This strategy is both promising and dangerous: while it makes us more ready for change, it also increases the chances of further fragmentation and complexity. Fortunately, these dangers can also be managed by growth: by creating spaces for peaceful contestation, law can channel complexity into shared problem solving, and counter fragmentation by nourishing trust.

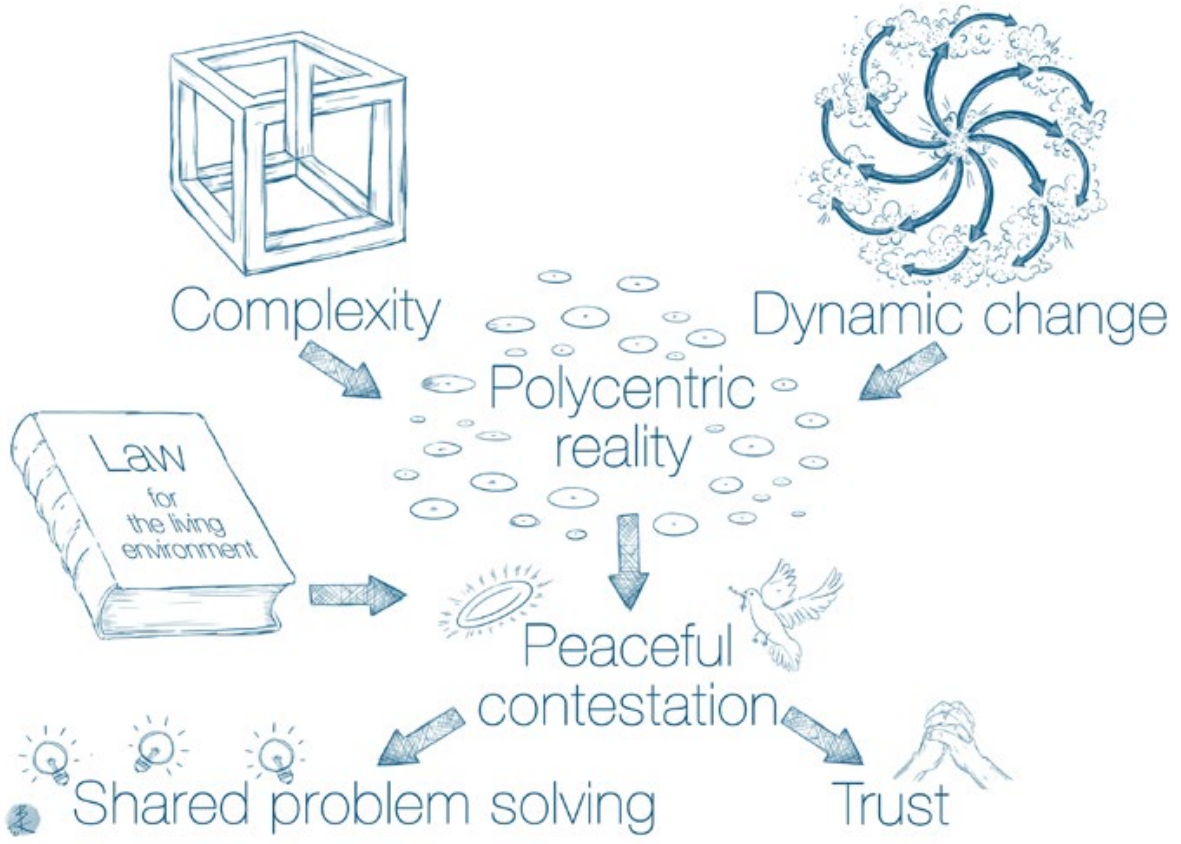




\section{Law in the Living Environment}

So let us start by addressing the challenge of defining what constitutes "law for the living environment" and how best to understand the role of law in the living environment.

The legal meaning of "law for the living environment" cannot be taken at face value. An analysis of each of these terms could easily fill today's lecture. In law - perhaps more so than in any other discipline - words matter.

The relationship between words and life can be more complicated than it first seems. Consider that, for the past two years, WUR has invested in the creation of "digital twins". ${ }^{7}$ Digital twins are virtual versions of living and non-living organisms and objects, such as plants, animals, humans but also food and supply chains. The purpose of creating such digital twins is to better describe and analyse complex processes and to better predict the future of these objects. As most lawyers, I had never heard of digital twins before arriving in Wageningen. However, as I learned more about them, I realised that digital twins fulfil much the same role in the life sciences as words do in law.

By assigning a legal term to processes, events and objects, lawyers give them legal meaning and are able to shape their future. For example, damage to the environment can only be addressed or regulated by law if it falls within predefined categories of "legal harm". Similarly, animals and non-human parts of nature are often legal non-entities without rights or standing. However, when we make them rightsholders - as the 'rights of nature' movement is keen to $\mathrm{do}^{8}$ - these entities are suddenly

\section{Words matter}
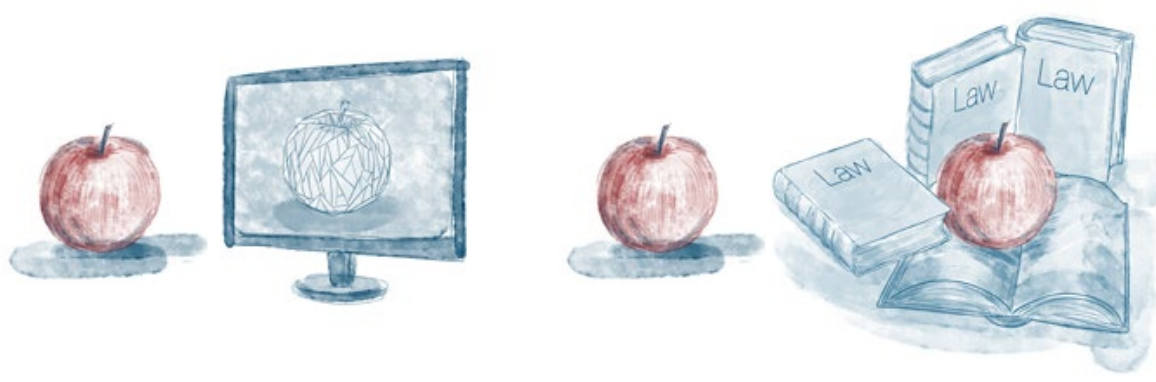
legally visible. Therefore, using specific words to describe different events or objects - "rightsholder" instead of "river", "consumer" or "patient" instead of "individual"changes how we view them as a matter of law, and makes them part of the legal fabric that contextualises our reality.

Through law, words affect and shape our living environment.

I view "the living environment" as encompassing those human and non-human entities and processes that we associate with the world around us, often colloquially referred to as "nature". In addition, it must include processes and entities that are man-made; since it is no longer possible to imagine our living environment without technologies, machines and artificial intelligence. This definition reflects an anthropocentric perspective, which in many ways is unavoidable in law, as law continues to be made by, and largely for, humans. ${ }^{9}$ Similarly, my primary focus today is on how humans shape the law, and by extension, our living environment.

This brings us to the challenging question of how to define "law" itself.

Defining this term invites two different types of questions:

The first question is a general one: what is law? One answer to this - as voiced by legal positivists - is that each society has created so-called "rules of recognition" that determine how legal standards can be created, modified or annulled. ${ }^{10}$ If a standard is set at the hand of such a rule, it becomes a law. Some legal scholars - such as natural lawyers and inclusive legal positivists - disagree with this approach: they believe that the creation of legal validity is conditional on the rule passing a minimum threshold of morality. This view immediately invites a new question, namely: what is the appropriate threshold of morality? ${ }^{11}$

The debate on what defines law is ongoing and unlikely to result in a final judgment. There is, however, growing consensus on the impossibility of developing a generally applicable and morally neutral theory about the nature of law. In thinking of law for the living environment, it is more important to be aware of these tensions than to identify a narrow set of rules and regulations that limit our field of enquiry. We should understand the law as a living instrument that is made and remade constantly by people through individual and collective decision-making and interpretation. Disagreements on what the law is--and what it should be--are an important part of this process.

The second question, which is always specific to the case at hand, is what is the 
applicable law in this particular case? In relation to our living environment, this question is often complicated due to jurisdictional overlaps and conflicts.

These complications become immediately clear when we consider the supply chains of most goods and services today, for example those related to our food system. The supply chain of most foods has become international, spanning many jurisdictions. As a result, the conditions related to food production, packaging, and marketing are set by multiple countries. Often, exporting countries change their laws to the requirements of their target market. This is particularly noticeable in the case of the European Union: the EU's market power is so considerable that many countries outside of the EU have changed their laws in order to be able to access the EU market. ${ }^{12}$ But even in this situation, determining which rules apply - for example, whether a banana labelled 'organic' is produced under the same conditions in India and in China - can be difficult, as their laws may define these terms differently.

This leaves us with one undefined word in today's lecture title: what to make of law for the living environment?

\section{Law for the living environment}

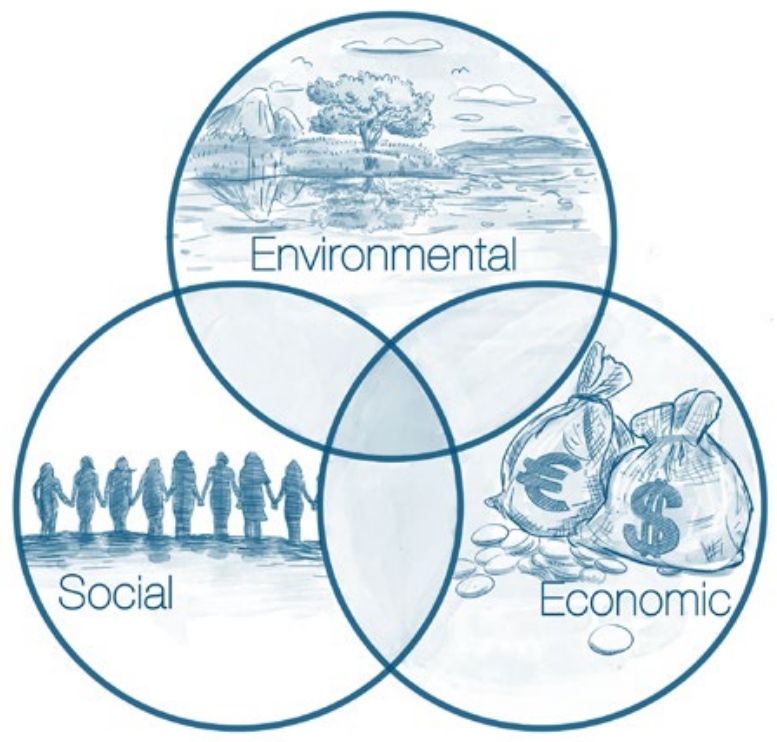


In order for the law to work for something, we need to define a normative goal for the law to work towards. The pervasiveness and power of the law means we can wield it as a shield to protect or a sword to pursue the things that we value. Historically, the law has promoted human flourishing for different groups in different ways at different times. ${ }^{13}$ Our search for definitions so far has highlighted how difficult it can be to come to a common understanding of law's normative aims. This is especially true for our living environment as there are so many potentially conflicting interests that are worthy of protection.

Nevertheless, a more complete version of today's title would be "Law for a sustaining and sustainable living environment." But as you may expect, the addition of these two words does not automatically lead to clarity: The concept of sustainability is in many ways too vague to provide legal guidance in specific cases: how should we balance economic, environmental and social interests against each other? And how can we set effective benchmarks for economic, environmental and social realities which are constantly changing?

In my view,$^{14}$ the concept of sustainability reflects an ambition to create a system that maintains a dynamic equilibrium: where environmental, societal, and economic actions do not over-exploit any one resource or actor, in the short or long term. In other words, a polycentric system. The choice for a 'sustaining' and 'sustainable' living environment reflects the importance of recognizing that in the human-nature relationship, there needs to be a recognition of mutual interdependence.

This approach still generates new questions: how to define the long-term? How to prioritize in situations where trade-offs are unavoidable? And what specific laws or principles to adopt to create and maintain equilibrium? The answer to most of these questions - as to so many legal questions- tends to start with "It depends...": a legal answer depends, always, on the specific circumstances of a case. ${ }^{15}$ The open-endedness of this answer brings us to the second important challenge: understanding the role of law in our living environment.

Law plays three roles with respect to our living environment:

Law creates the processes for setting the goals related to our living environment and its sustainability; the law helps us implement these goals; ${ }^{16}$ and it helps us enforce them.

When we set, implement and enforce goals, the law steers us towards certain substantive outcomes based on past practices and decisions. In thinking of law, and legal scholarship, as a conduit for societal change, we must therefore be constantly reminded that the law reflects and expresses existing social norms ${ }_{1}^{17}$ which will change 
within current and future generations. Unlike laws of nature, human laws are ours to change in light of such changing priorities and preferences.

In reflecting on what constitutes law for the living environment and the role of law in shaping it, it is clear that the law plays an important role in reflecting our choices, and shaping our choices. The law often does this explicitly and coercively. But it can also do this much more subtly by simply setting the conditions that nudge us into certain directions. ${ }^{18}$ Law's coercive power makes it easy to overstate its predictive ability. ${ }^{19} \mathrm{I}$ am sure that most parents and educators here are keenly aware that rules do not always lead to the intended results and may have unexpected side-effects. Put simply: the law is very good at creating a range of possible outcomes, but much less good at predicting and ensuring one specific result.

While perhaps obvious, this reality is problematic since legislators often do not incorporate these uncertainties into their thinking and policies. The fact that the possibility of unintended side-effects, or failure to reach one very specific result, is not taken into account beforehand, may increase the risk of potential negative effects, and the range of unknown futures.

\section{Shaping our Living Environment}

The ability of the law, and by extension regulators, to predict, and plan for, this range of possible outcomes is affected by ever-increasing complexity and dynamic changes of our living environment. These realities affect every area of the law but are particularly noticeable in areas of the law that relate closely to our living environment, such as environmental law.

\section{Complexity}

Let me start by describing the increased, and increasing, complexity of our living environment and how this complexity interacts with law. ${ }^{20}$

Law regulates human behaviours that impact other people, animals, our environment, and ourselves. As mentioned, predicting the precise effect of these behaviours is difficult since people may respond differently than expected.$^{21}$ In addition, there may be intervening events that change the effects of the regulated behaviour. Apart from regulating human actions, the law can also choose to intervene with non-human forces that shape our environment, including by mandating human action. For example, much of climate change adaptation policy centres on lessening the effects of climate change on humans and on the 


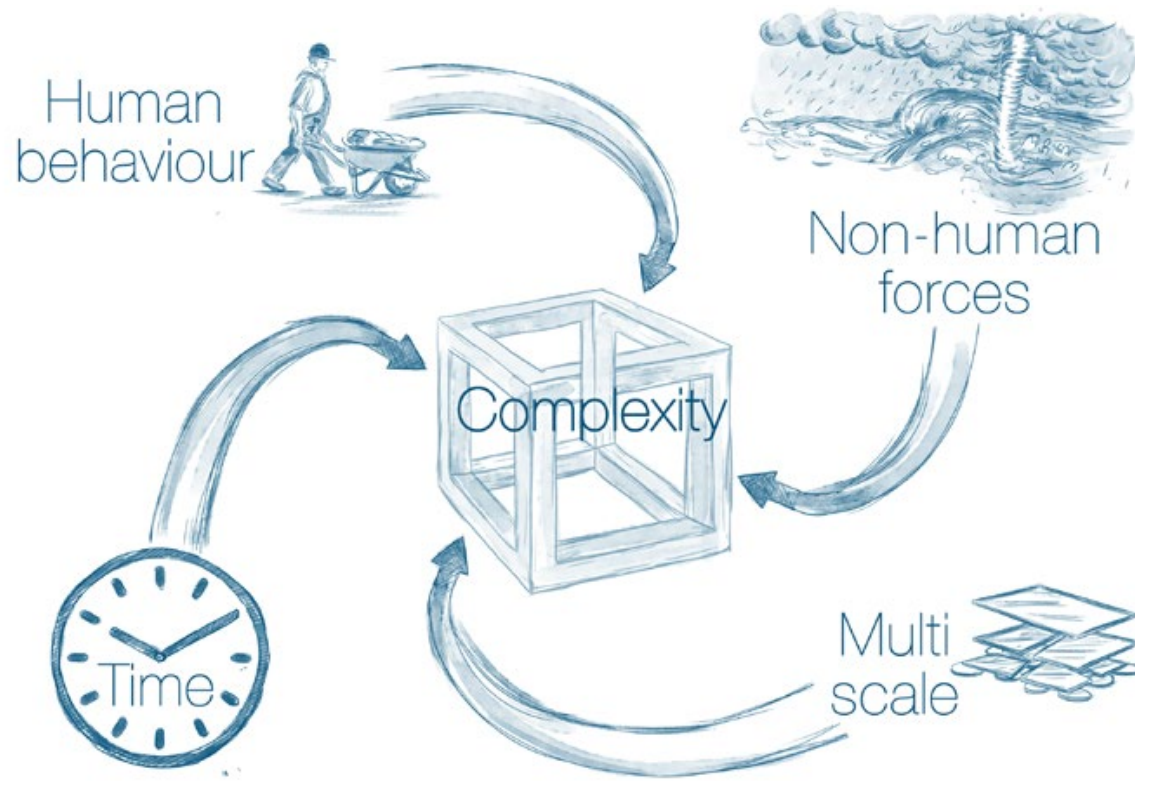

environment. In this case, the law attempts to slow down natural processes that affect our living environment.

Complexity is inherent to most of these processes and interactions. These ecological, technological, economic and social complexities, moreover take place across several jurisdictions, each with various levels of regulation - highlighting the multiscale nature of most social processes. Together with the temporal dimension, including unknown or uncertain short- and long-term effects, this creates uniquely complex realities. ${ }^{22}$ As natural science and environmental science have illuminated these complexities, the information that lawmakers need to process in order to make, or apply, the law has become more complex. As a result, the law itself has become ever-more technical and complex. Finally, the multiscale nature of environmental, economic and social processes has resulted, arguably rightly, in more complex systems for creating and applying the law.

The proliferation of modern technologies has also made the law more accessible for example through the creation of online databases and the increased codification of legal rules across and within jurisdictions. This development has been aided by a greater emphasis on the need for transparency in decisionmaking. ${ }^{23}$ These improvements can however not counterbalance the proliferation of complex legislation and legal processes. 
Many of examples of this can be found in the European Union, which on the one hand champions transparency and participation in law making, for example by publishing the 'legislative train schedule' ${ }^{24}$ This schedule provides an easy way for citizens to stay informed about the stage of legislative action. On the other hand, the EU continues to rely heavily on processes such as comitology, ${ }^{25}$ where many crucial details of legislation are set by experts in closed sessions.

The desire to base law and legal decisions in factual knowledge about the present and future is complicated by the unknowns that characterise our futures. Law provides, for better or worse, the stability that people and organisations need in order to plan their lives and actions. As a result, the law is often slow to respond to changes. Balancing legal adaptivity and legal certainty under conditions of incomplete information and complexity is a considerable challenge.

\section{Dynamic change}

The need for adaptivity is further underlined by the fact that our living environment is subject to dynamic change. This creates a constant challenge to the type of stabilizing boundary-setting on which law otherwise relies: how can we set meaningful limits and boundaries in an environment that is constantly and interactively changing and evolving?

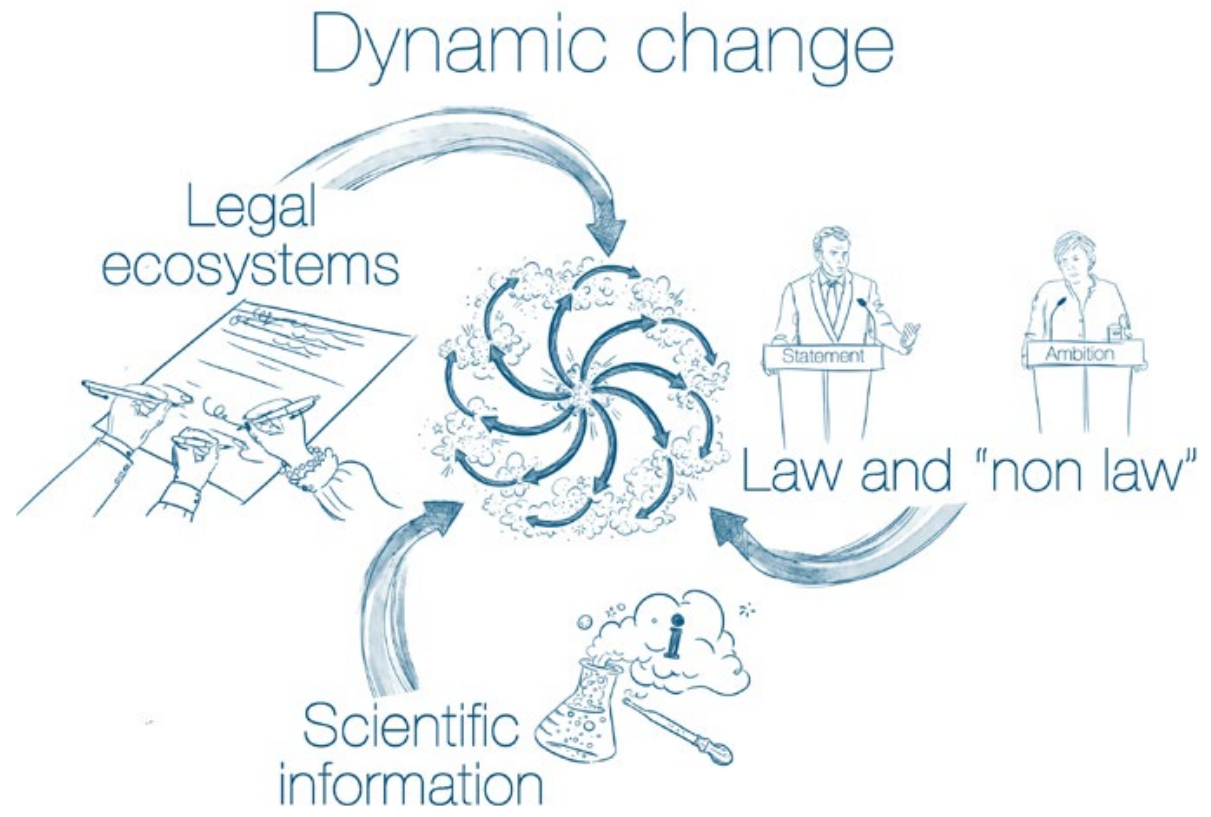


The creation of transnational law as a legal ecosystem, ${ }^{26}$ and as a presence in other legal ecosystems, illustrates the process of dynamic change. Transnational law differs from traditional international law in that it can be co-created by private actors. By including private actors in rule creation, transnational law changes the system of rules that individuals and states are subject to, and introduces additional sources of growth, complexity, and change. Traditional legal actors, including courts, increasingly recognize rules that are part of transnational law. This changes national and international legal systems further, even as it feeds back to impact the development of transnational law itself.

Feedback effects, a key part of the process of dynamic change, can also be identified with respect to the boundaries between law and "non-law". In May 2021, a Dutch district court decided on a case between a number of Dutch NGOs against Royal Dutch Shell. ${ }^{27}$ The question before the court was whether Shell had fulfilled its duty of care towards society in light of its contribution to greenhouse gas emissions, and by extension, climate change. The Court used soft law instruments - which are considered unenforceable by courts - in order to define Shell's duty of care..$^{28}$

In addition, the judiciary relied heavily on scientific environmental information in

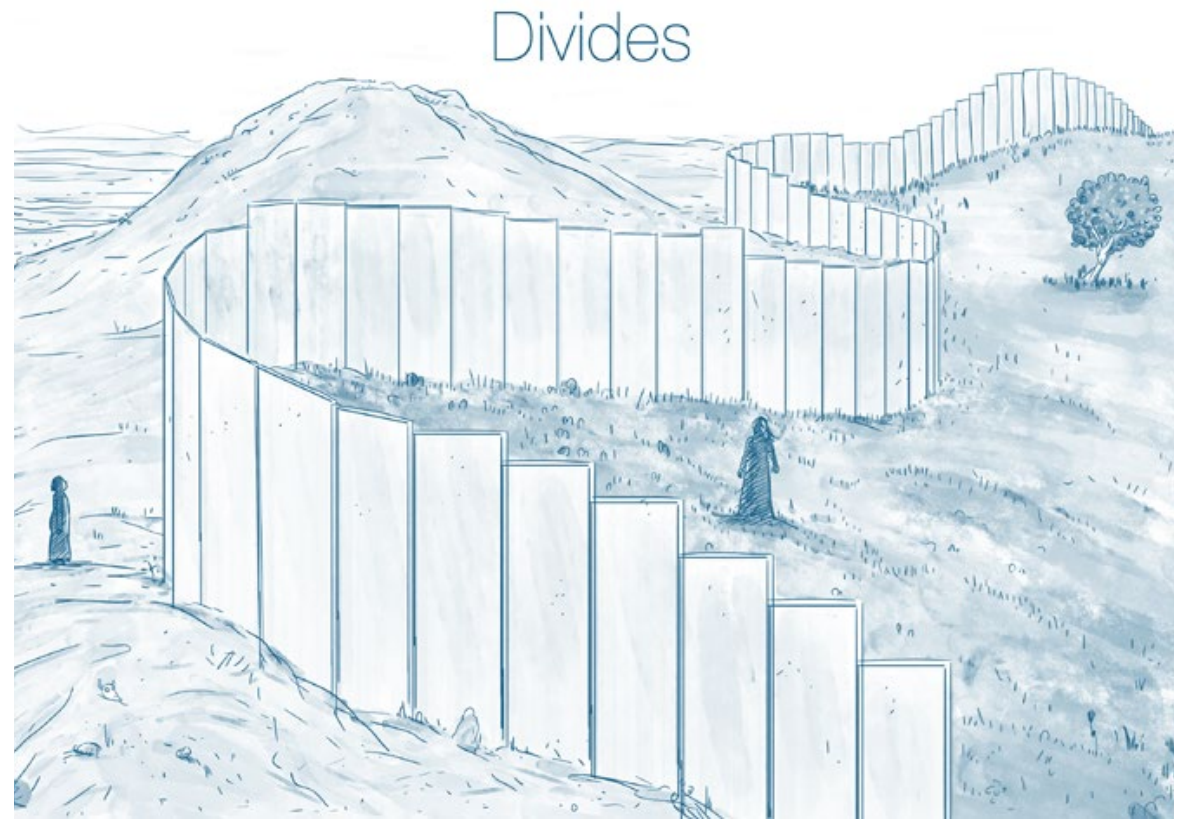


shaping its judgment. More generally, there has also been an increased sharing of methodologies and perspectives between different fields of law, and across disciplines.

At the same time, dynamic change can invoke greater rigidity and the hardening of political, ideological, economic and social divides. Many of these developments are informed by, and inform, increasingly stark ideological positioning and entrenchment of disciplinary methodologies. Crucially this includes the subjectification of science, which reframes questions of climate change and vaccination as questions of opinion and belief, rather than fact.

The rejection of dynamic change, and the increasing interdependence of our social systems, is keenly expressed through the drawing and enforcing of artificial - often legal - boundaries between places or groups of people. Law can be used as an explicit and implicit tool to achieve these purposes.

In order to create effective law for our living environment, these two realities - of complexity and dynamic change - need to be accommodated in our legal approaches. To effectively regulate a complex, dynamically changing environment, law must cultivate those same qualities. A living environment deserves living law.

\section{Polycentric Futures}

One of our strongest responses to the challenges that the living environment presents is the strategy of polycentricity - of having, recognising, and cultivating "many centers" of growth, change, and response.

In governance theory, polycentricity speaks to regulatory realities where there are multiple centres of decision-making that coordinate and compete with each other on different issues. Individuals can move freely between these centres and there are no monopolies of power. Instead, there are constantly shifting vertical and horizontal relationships that involve both public and private actors. ${ }^{29}$

Descriptively, polycentric governance theory is able to capture complex systems such as the European Union in a more complete way than other theories, such as federalism. ${ }^{30}$ Normatively, polycentric governance theory adds to approaches such as multi-level governance theory by including a clear normative aim for this type of governance. The aim of polycentricity - as initially developed by Vincent and Lin 


\section{Polycentric futures}

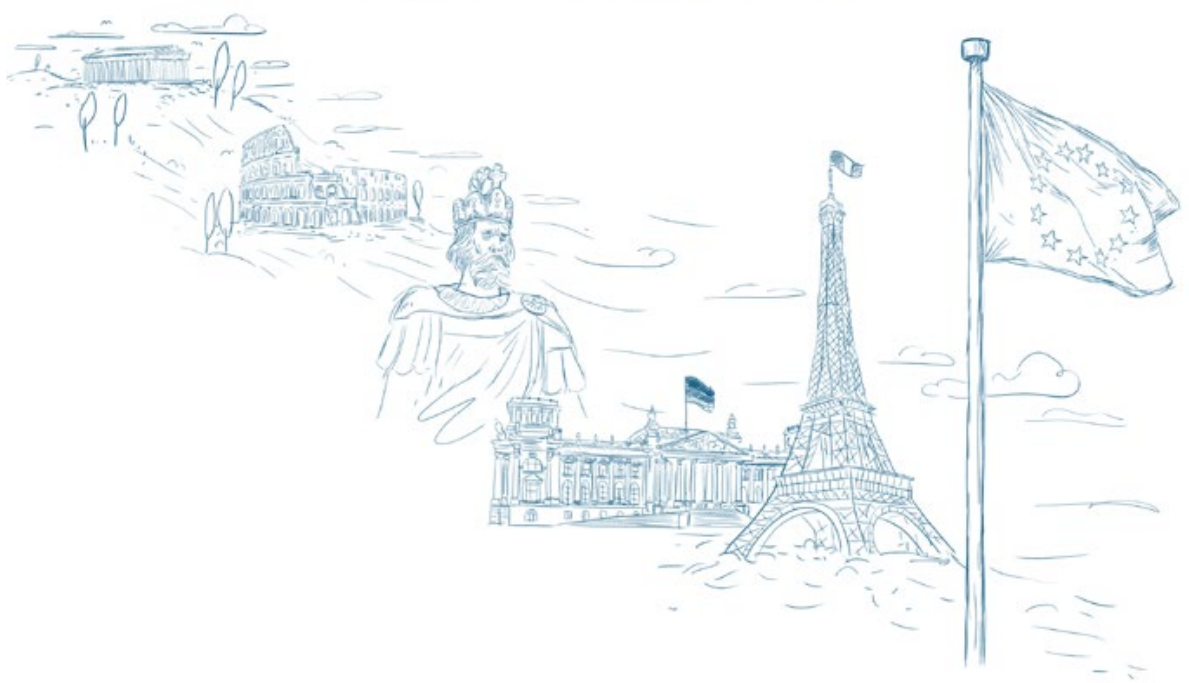

Ostrom - is to ensure self-governance. ${ }^{31}$ Much like the law, self-governance is not inherently "good". Criminal organisations often present as polycentric systems. The Ostroms assumed that most polycentric systems would function under a larger system of shared rules, which set moral parameters for behaviour. In this, they saw an important role for the "rule of law" in polycentric systems. ${ }^{32}$

Polycentric systems themselves are inherently complex and dynamic, constantly creating new equilibria between its multiple centres. Prerequisites needed to maintain this equilibrium include access to information, justice and the capacity to learn. These polycentric systems do not only have upsides: their dynamic and complex nature can compound existing complexities and risks putting too high an informational burden on individuals, resulting in the exclusion of certain groups. This can lead to fragmentation and even polarisation.

So where do I see the potential of these systems in regulating our complex and dynamic living environment? How can this perspective of polycentric governance and the role of law in such systems - provide us with the answers we need? 


\section{Law for conflict}
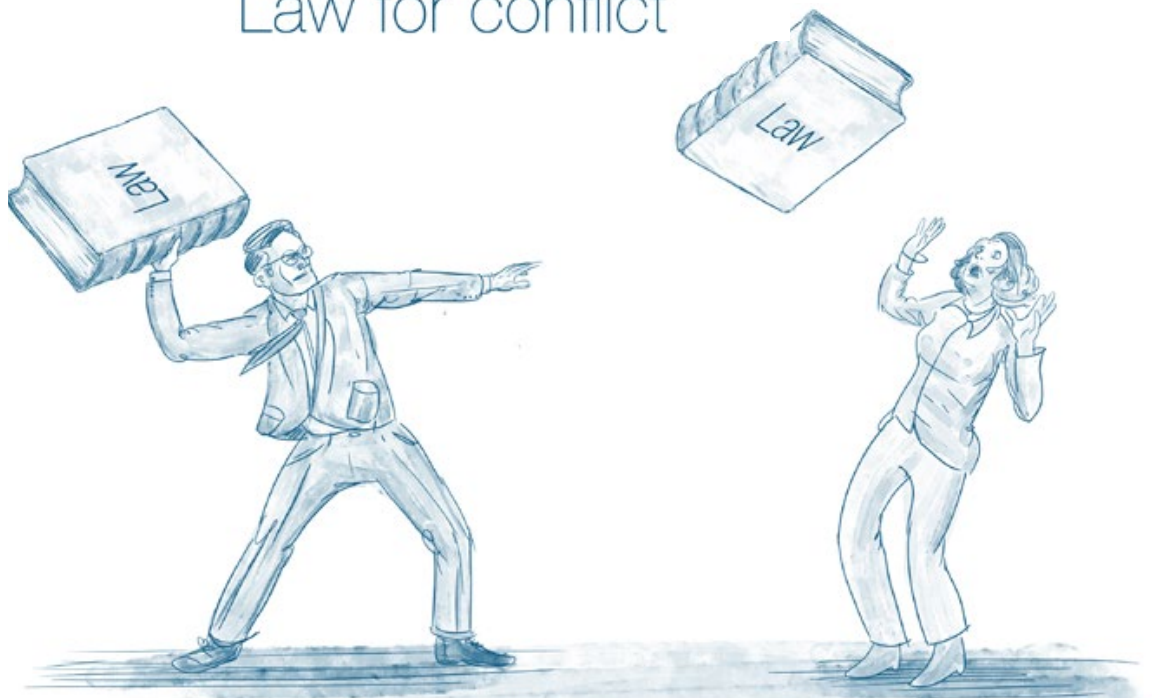

Challenges related to our living environment - such as climate change, the scarcity of resources, global health threats - can foster significant conflict. In view of the complex and dynamic nature of these challenges, it is no longer enough for law to try to pre-empt or regulate these conflicts. Rather, we should look to use law to create a space for peaceful contestation about the nature of these challenges, our goals in addressing them, and our methods for achieving these goals.

\section{Law for peaceful contestation}

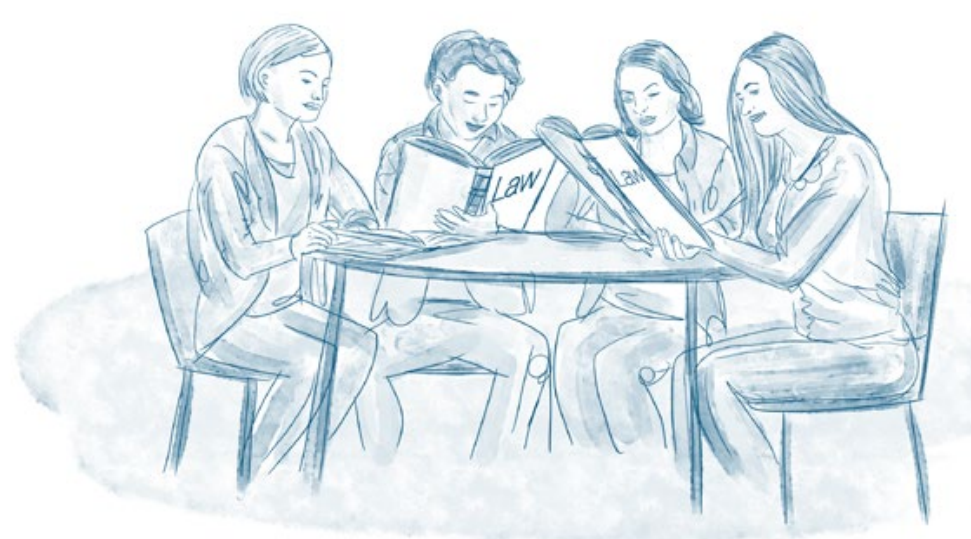




\section{Peaceful contestation}

Peaceful contestation is a constructive expression of natural tensions between people's individual preferences: a way for people to sharpen their own views and to eventually collaborate. Peaceful contestation is a key attribute of polycentric systems and offers two solutions to complexity and dynamic change:

First, peaceful contestation contributes to better problem-solving, especially for complex problems. Through peaceful contestation, the definition and solving of shared problems can be improved. There is empirical evidence that shows the success of collective deliberation in terms of "better" outcomes, ${ }^{33}$ and that the process of deliberation makes individuals more open to changing their initial preferences. Though seemingly chaotic, constructive peaceful contestation requires carefully constructed social spaces and processes, in which law plays an important role. ${ }^{34}$ Without these spaces and processes, it is impossible to create and maintain the level of dialogue, expertise and participation that is needed for constructive contestation. Public participation is one of the most common and fundamental forms of peaceful contestation. If performed successfully, public participation involves shared problem definition and problem solving where clashing opinions with respect to a specific situation can be expressed before a course of action is set. Crucially, public participation should be able to question a dominant discourse set by a privileged institution or actor. ${ }^{35}$

\section{Problem solving}

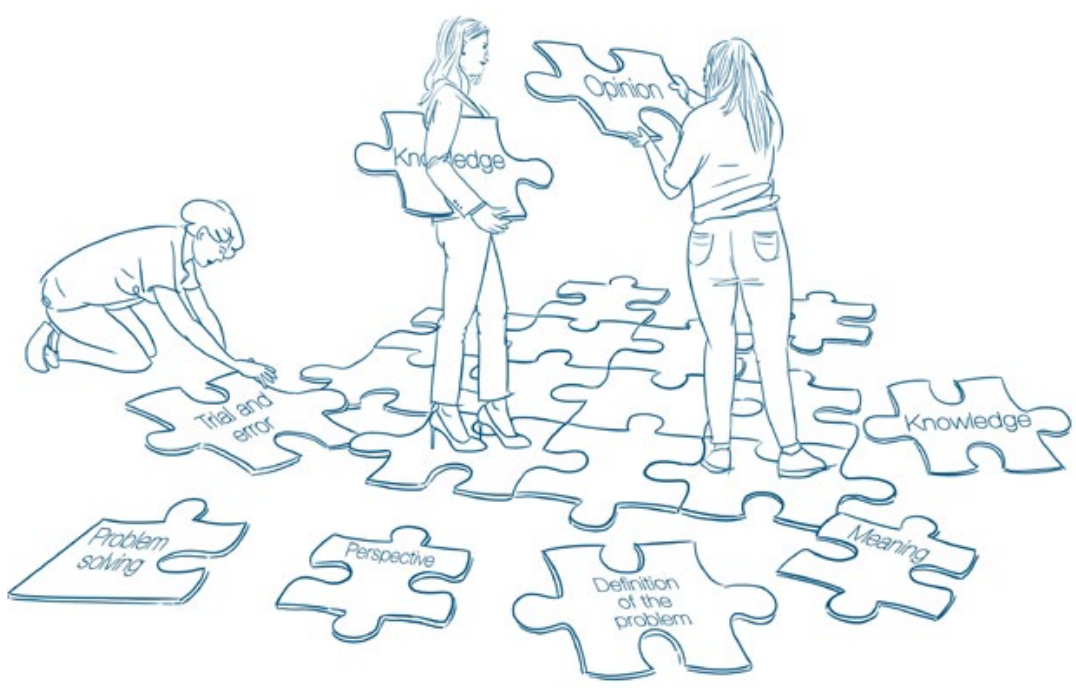


When left unaddressed, complexity can be linked to lower participation rates, which in turn lead to greater dissatisfaction with representative democracy and an erosion of trust in politics. ${ }^{36}$ So while the process of shared problem solving may be complex and time consuming in itself - the inclusive nature of the process improves our understanding and approach to the problem, and has positive spill-over effects on our ability to self-govern in a complex and dynamic reality.

Second, peaceful contestation helps to cultivate trust, which can address fragmentation and polarisation.

In talking about peaceful contestation and trust, let me start with a living example. Since Darwin, trees were thought of as disconnected "loners", competing with each other for water, nutrients and sunlight, with the winners shading out the losers and sucking them dry, painting a picture of forests as battlegrounds for survival of the fittest. There is now substantial scientific evidence that refutes this characterisation. It shows instead that trees of the same species are communal, form alliances with trees of other species, and have evolved to live in cooperative, interdependent relationships, maintained by communication and a collective intelligence similar to an insect colony. ${ }^{37}$ Humans, like trees, are social beings, and our relationships with one another are and can be cooperative and supportive, even as they involve negotiating and managing boundaries and resources.

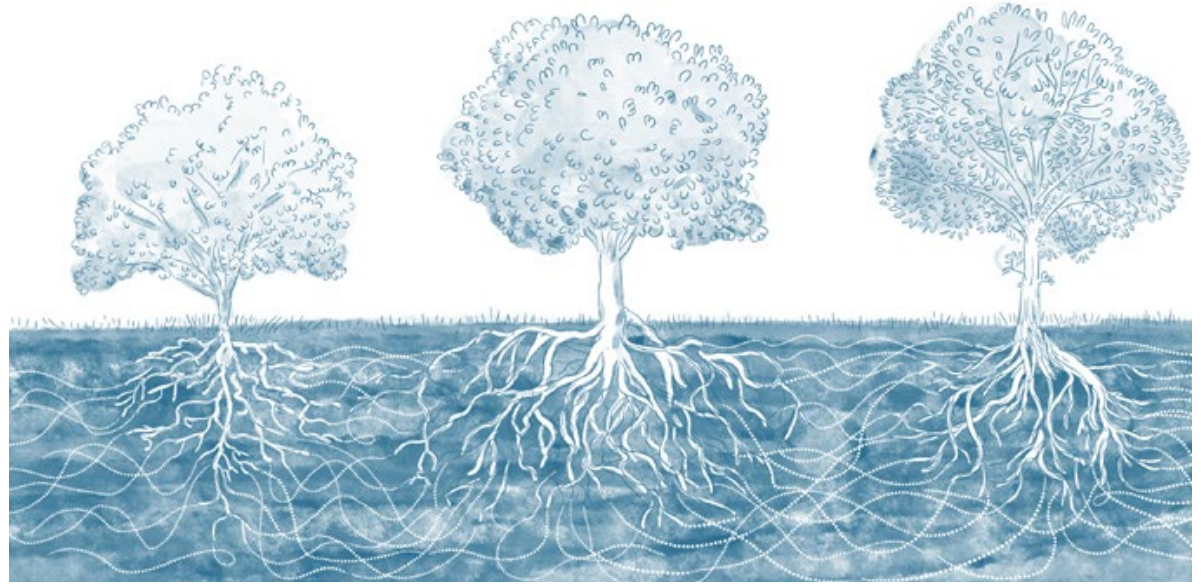

Law has become one of the key ways in which humans regulate and nourish societal relationships. Law affects our personal relationships - between spouses, with our children, with our neighbours; our business relationships - between employer and 
employee, consumer and producer; and societal relationships more generally relationships between people who we may never meet or know each other personally, and our relationships with, and between, governmental institutions. Law also regulates the relationships between nation-states, even if the law cannot be enforced against them in the same way as it may be against individuals.

This formalisation of relationships reflects specific policy choices. For example, the formalisation of employment relationships can create safeguards for both employees and employers. The formalisation of sales contracts can regulate information asymmetries between buyer and sellers. In regulating relationships, formalization also tries to pre-empt conflict. And if this is not possible, it allows for a peaceful, non-violent, way to address conflict.

By regulating relationships in this way, law can also set the stage for "trust-producing" conflicts. These types of conflicts incentivise individuals to "self-enforce the rules of the game and to change those rules in an orderly way"..$^{38}$ These dynamics strengthen trust among the actors and within the system as a whole.

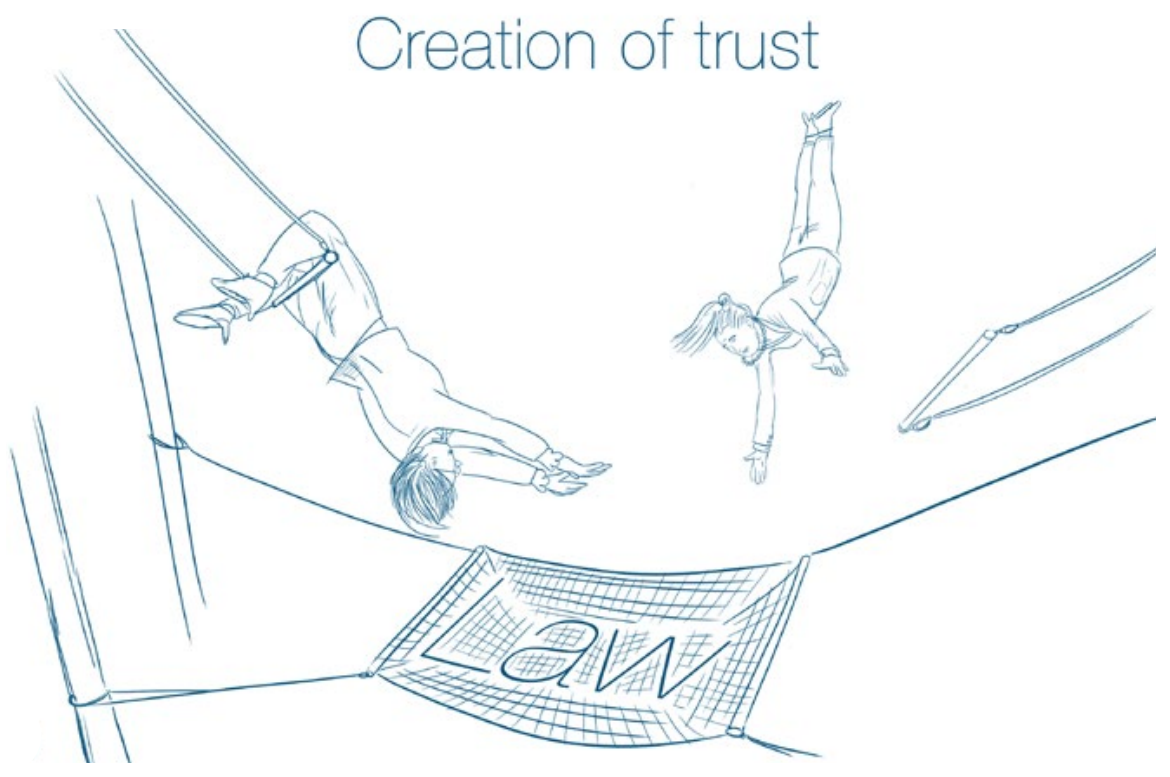

One of the most challenging things about trust is that the building of societal trust tends to start at a small scale, locally or within the confines of the nation state. ${ }^{39}$ Once these local trust relationships exist, we use the assessment of 'trusted' others to help inform our feelings about the trustworthiness of institutions and processes. ${ }^{40}$ The 
local origins of trust prove a real challenge in the context of complex transboundary problems such as climate change, and within complex systems such as the EU. ${ }^{41}$

There have been many attempts to "impose" trust between EU actors in a top-down manner, for instance by the European Court of Justice. For example, the Court created the legal doctrine of "mutual trust" between Member States, which provides that Member States must trust that all other Member States observe EU law, particularly its fundamental rights. ${ }^{42}$ This species of "trust" - if in fact, we can call it that - is not created by trust-producing conflicts or sustained interactions. Rather, it pre-empts these events and imposes a presumption of trust. This proxy for authentic trust can be counterproductive in displacing the processes that allow for authentic trust to grow.

These dynamics, which the law can shape in important ways, are especially important in situations of 'mutual vulnerability', such as climate change and the ongoing pandemic. ${ }^{43}$ These situations can help to increase trust as people can bond over a common enemy. However, it can also push people to prioritize their selfinterests, thereby reducing, or even destroying, existing trust. ${ }^{44}$

The law cannot impose trust, but legal processes can create spaces where trust is given the conditions it needs to grow through sustained and safe interactions. This is particularly important in light of transboundary problems with intergenerational implications, such as climate change, that challenge our existing legal processes and laws, and our deliberative ideals. ${ }^{45}$

\section{Law for sustaining and sustainable living environment}

Legislation for a sustaining and sustainable living environment must account for the complex, dynamically changing reality of the world around us. These realities are making our institutional environment more polycentric, which in turn can reinforce complexity and fragmentation. Rather than looking for simplification as a panacea to these challenges - I propose we meet growth with growth: that we embrace the fact that our reality is complex and dynamic and that our institutional and legal reality must develop in a similar way. This development can be a positive one, particularly if we use the law to create processes and spaces for peaceful contestation in ways that add to shared problem-definition and problem-solving, as well as trust-producing conflicts.

Adopting a growth mindset with respect to the polycentric nature of our living environment, and our legal realities, can moreover allow the law to develop into an instrument that reflects a plurality of voices: not only the language of power, but also a vocabulary for problem solving and cultivating trust. 


\section{Researching for the living environment}

Let me briefly summarise where these reflections have brought us and what its implications are for researching for the living environment.

I have argued that law is one of the most important forces shaping our living environment, but there is a degree of unpredictability related to the effects of law. The realities of ever-increasing complexity and dynamic change call for a different type of legal response - one that I believe points towards a more polycentric future. In this future, law should look to create more spaces for peaceful contestation, and that through this role, the law can counter complexity through joint problem solving, and heal fragmentation through trust.

In order to better prepare our students and society for new unknown futures, I believe that these realities invite the creation of a new species of research, researcher and educator, fueled by interdisciplinary methods and insights, for whom I am committed to building a habitat at Wageningen.

The call for a more polycentric view of our shared future and the adoption of a growth mindset to face its challenges provide key nutrients for this new habitat. A living garden, where law for the living environment can grow and flourish. But this plan is not meant to languish on paper; to grow a garden, we must actually plant things, not just plan to plant. Someone must dig in the dirt; someone must tend the soil and the seeds, manage the changing weather and even reap the harvest.

My plan for this growth and cultivation is set out in our chair plan for the coming five years. Our research agenda is structured around three research lines, one on environment and energy; one on food systems; and one on business and human rights. All of these lines interrelate and are connected through our joint focus on systemic change, transnational law and transdisciplinary methodologies. ${ }^{46}$

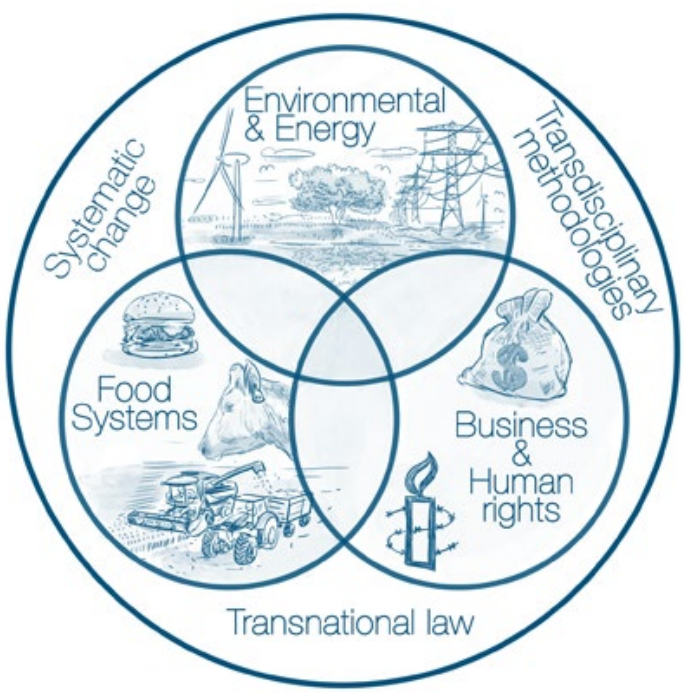


What makes the Law Group a special place for this research is its embeddedness in the larger ecosystem of Wageningen University, within a department of Social Sciences that is structured around interdisciplinarity - and its national and international connections with others working on these issues. Interdisciplinarity is much more common today than it was even 15 years ago - particularly between the social sciences. Legal scholarship has benefitted from, and contributed to, this development. As today's conference has shown, the search for shared languages and approaches is ongoing and the potential virtually unlimited. The Law Group's presence in a life sciences university allows for an even broader approach to interdisciplinarity.

Within legal academia, the Law Group is of course not alone in looking for answers to the questions I spoke about today. The impacts of law on our living environment are increasingly widely studied, also by for example by scholars of tax law, criminal law and competition law. Nevertheless, the continued overspecialisation of lawyers in one field can prevent the holistic approach that we need to realise important goals, such as a circular economy. This means we need doctrinal legal scholarship as well as interdisciplinary methods to provide a more coherent legal landscape on these issues and to help regulators in finding their way through this landscape. Our collaborations with the city of Amsterdam through the AMS Institute are exemplary of this type of work: ${ }^{47}$ for example, through the creation of digital tools based on design thinking and rigorous legal analysis in order to help regulators to find new ways to legislate for circularity.

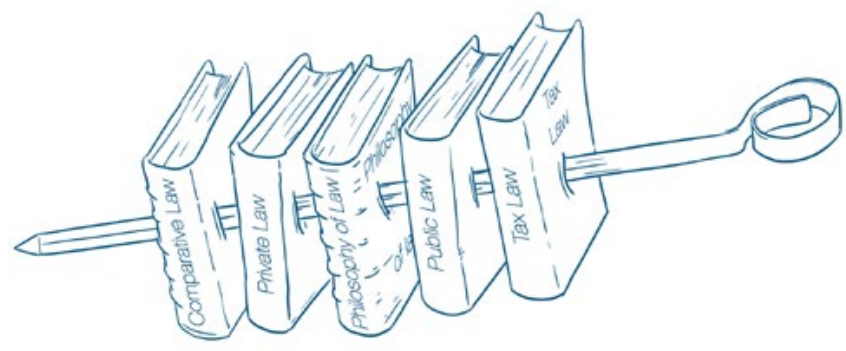

Finally, we need to populate our habitat with diverse, forward-looking, legally trained but interdisciplinary researchers, aware of local realities, nested in networks that go beyond their own jurisdictions and disciplines, and who can build bridges within legal academia so as to foster more 'interdisciplinary' work there. These characteristics also help us be better educators for our students, some of which come with prior legal training but many of whom are shaping their living environments through different fields of expertise and want to learn how to channel this expertise through legal realities. 


\section{Researchers}

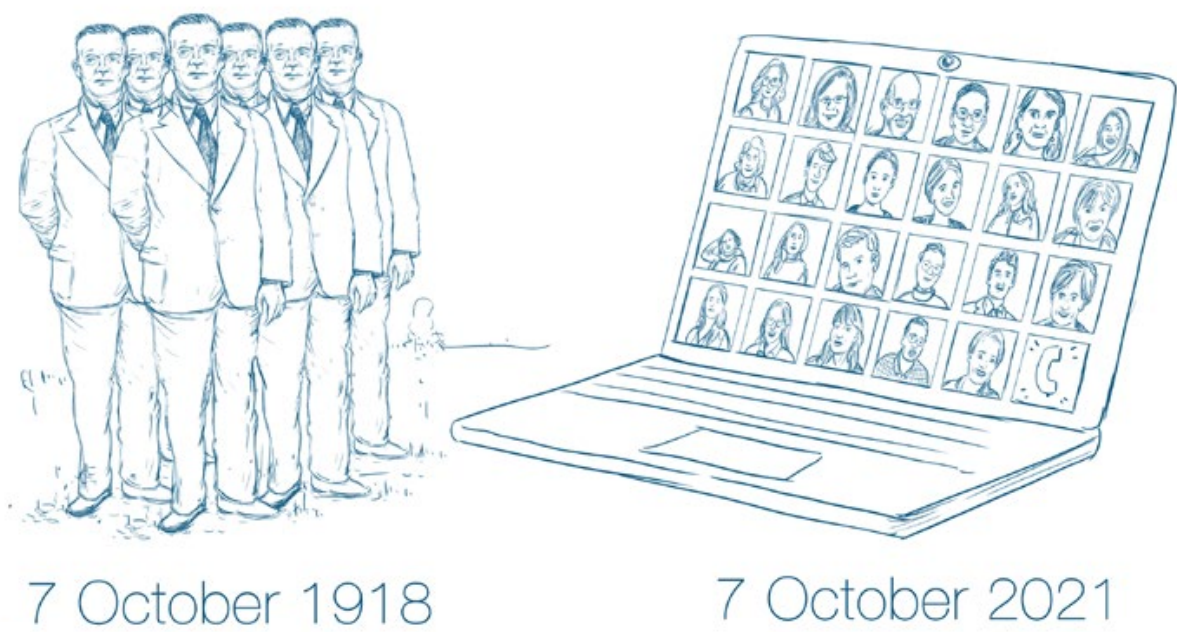

Like my predecessor with whom I began my talk, I hope that I have been able to show you the relationship between our realities and the law. Law is everywhere and shapes our lived reality in pervasive ways. To grow and change with our dynamic and complex living environment, the Law Group's habitat will nurture scholars to do just that.

\section{Word of thanks}

I would like to conclude with expressing my gratitude to the people that made today possible.

First, I thank the current and past members of the Law Chair group. The past few years have been challenging in many ways and without their dedication to the Group, the University and its students, we would not be here today. I am grateful for their warm welcome, trust and guidance.

Over the past two years, our group has grown exponentially and it has been one of the most rewarding parts of my job to welcome such talented people and to help them make Wageningen their academic home. Alongside our tenure trackers, this includes our post-docs, PhD researchers and students. My main professional ambition is to repay their trust by ensuring a stimulating, supportive and welcoming habitat for them and those who will join us in the future. 
The growth of our Group is only possible due to the confidence placed in me by the Board of Wageningen University, and in particular our Rector Magnificus Arthur Mol, who was instrumental in preserving this Chair Group for Wageningen. His support, and the investments of the Social Sciences Group, led by Jack van der Vorst, have made sure that the research agenda I shared with you today will not remain an unrealised future.

I also want to thank my Wageningen colleagues from around the University. I came to Wageningen in search of a truly interdisciplinary environment; what I found has exceeded my expectations. Not only in terms of collaborative potential, but also in terms of institutional complexity! I am therefore especially grateful to the university support staff for their help and patience while I learned about these systems.

The daily collaboration with colleagues in the Sustainability Governance section, including Simon Bush and Katrien Termeer, has already led to a number of successful projects. I very much look forward to realizing our future plans for the Wageningen Centre for Sustainability, together with the Forest and Nature Conservation Policy Group.

From across the university, many shared their experience of joining Wageningen as a 'foreigner' and helped me reintegrate to Dutch academia. This year, I've been lucky enough to join the Wageningen Young Academy: in its ambitious members I have found invaluable allies in fighting for an ever more inclusive, diverse, fair and rewarding academia.

I am also grateful for the many colleagues in the Netherlands who greeted my appointment with enthusiasm. Being able to work more closely and more frequently with colleagues in the great universities in our small country has greatly enriched my experience and I look forward to integrating the LAW Group even more into this network.

My professional journey started in 2008 when Edgar du Perron, then-dean of the law faculty at the University of Amsterdam, funded my law and economics PhD proposal and referred me to Giuseppe Dari Mattiacci. At the time, I had no conception of how privileged I was to be able to write on my own topic and to have the benefit of Giuseppe's supervision. Giuseppe - thank you for setting the bar so high and for making sure I would rise to meet it. As the focus of my PhD became clear, Marc Pallemaerts - professor in EU environmental law - joined my supervision team. Marc passed away unexpectedly and much too soon in 2014 . He continues to be missed. 
Between 2008 and today, I benefitted from the mentorship of numerous academics across the world. Your generosity in terms of time, trust, and opportunity have changed my personal and professional life, and made the decision to dedicate my life to academia such an easy one.

A necessarily incomplete list includes: my colleagues from the Ostrom Workshop, particularly Dan Cole; the members of the Society of Environmental Law and Economics; the editorial team of the Transnational Environmental Law journal; members of the Ius Commune Research school; and former and current colleagues at the University of Amsterdam, NYU, Harvard, Oxford University, Bocconi University and the ETH Zurich. Thank you for making academia a better place. Many of you have become co-authors and close friends; Arden Rowell represents the best of both these categories, and I am grateful for having her in my life.

I also want to thank the speakers of today's conference. They present some of the best of the complex and dynamic system of ideas that is my academic living environment. Aarti Gupta, Elbert de Jong, Karen Bradshaw, Raul Pacheco-Vega, Cass Sunstein, Anniek de Ruijter and Smita Narula, thank you for making time to share your thoughts on our unknown futures and for making me hopeful about our ability to face them.

Today would not have been possible without the tireless efforts of Lin Batten and Sandra Vermeulen, as well as the hard work of Mark Beumer, the staff of the WICC, WAVRU and the Aula. Last but most certainly not least, I want to thank Bas Köhler. I am immensely grateful for, and impressed by, Bas' incredible skill, whose drawings have made today's lecture come to life. Thank you all for making today possible - and great fun.

Despite my love for academia, and my general good fortune in terms of colleagues and opportunities, by far my proudest achievement is to have built a full and rich life, of which this job is one important part. The most important part however, is Chris. You, Tuur, Tam, and Audra, are everything I need and more than I deserve. Once they are old enough to watch this lecture, I hope it will make our kids proud, hopeful, and not too bored. 


\section{Ďakujem Cảm on ban Bedankt Dankon Mulțumesc Děkuji Tack \\ Hvala vam \\ Dankewol \\ Takk skal du ha Asante Merci 감사합니다 \\ 谢谢 Благодаря ти Terima kasih Thank you \\ Спасибо \\ Dziękuję Ci

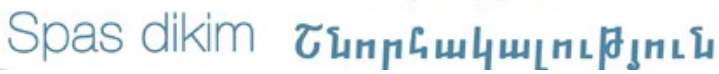 \\ Mauruuru Tapadh leat \\ Köszönöm \\ Go raibh maith agat \\ Gràcies كل اركش \\ Matur nuwun}

I would not be here, or want to be here, without the love and support of my family and friends. Thank all of you for being in our lives. I am especially happy to be able to spend this day with my parents, my brother and my sister-in-law - who make every day one of peaceful contestation, problem solving and trust. A special thank you to Anne for being the extra pair of hands, eyes and heart in the complex and dynamic challenge of taking care of our little clan.

Finally, I want to acknowledge the many women - and men - that continue to create spaces in academia for other women and minorities. I am grateful and will pay it forward.

Ik heb gezegd. 
$1 \quad$ Climate Change 2021: The Physical Science Basis. Contribution of Working Group I to the Sixth Assessment Report of the Intergovernmental Panel on Climate Change [Masson-Delmotte, V., P. Zhai, A. Pirani, S. L. Connors, C. Péan, S. Berger, N. Caud, Y. Chen, L. Goldfarb, M. I. Gomis, M. Huang, K. Leitzell, E. Lonnoy, J.B.R. Matthews, T. K. Maycock, T. Waterfield, O. Yelekçi, R. Yu and B. Zhou (eds.)], Cambridge University Press.

2 M. Blyth, 'There is no 'getting back to normal' with climate breakdown' (11 August 2021) The Guardian, available at www.theguardian.com/commentisfree/2021/aug/11/no-getting-back-tonormal-climate-breakdown-ipcc-report.

3 See e.g. C. Dweck, Mindset: The New Psychology of Success (Random House, 2006).

4 P. de Visser, 'Het agrarisch recht aan de Landbouwhogeschool' (1986) in Recht in ontwikkeling - tien agrarisch-rechtelijke opstellen (Kluwer), available via https://edepot.wur.nl/309095.

5 J.C. Kielstra, 'Recht en Werkelijkheid' (7 October 1918), available at https://edepot.wur.nl/248738.

6 Ibid., at 19 (unofficial translation by author, original text reads: "Moge het mij gegeven zijn $\mathrm{U}$ het verband tusschen die werkelijkheid en het recht te doen zien, om U beter voorbereid het leven te doen ingaan; dan zal ik mijn doel bereikt achten.").

7 See www.wur.nl/en/Research-Results/Research-programmes/Research-investment-programmes/ Digital-Twins.htm (last accessed 16 October 2021).

8 E.g. K. Bradshaw, Wildlife as Property Owners (University of Chicago Press, 2020).

9 For an alternative view, see the important work on Earth System Law, www.earthsystemgovernance.org/research/taskforce-on-earth-system-law/\#: :text=The\%20concept\%20of\%20earth\%20 system $\% 20$ law $\% 20$ is $\% 20$ intended $\% 20$ to $\% 20$ reflect,governance $\% 20$ of $\% 20$ earth $\% 20$ system $\% 20$ transformation (last accessed 18 October 2021).

10 H.L.A. Hart, The Concept of Law (Oxford University Press, 1961).

11 R. Dworkin, Law's Empire (Harvard University Press, 1986).

12 A. Bradford, The Brussels Effect: How the European Union Rules the World (Oxford University Press, 2020).

13 See e.g. S. Narula, 'Reclaiming the Right to Food as a Normative Response to the Global Food Crisis' (2010) 13 Yale Human Rights and Development Law Journal 403-422.

14 Much has been written on (the challenge of) defining sustainability. See for example, H.M. Farley and A.A. Smith, Sustainability: If It's Everything, Is It Nothing? (Routledge, 2014) and L.P. Thiele, Sustainability (Polity Press, 2013). See also J. L. Ramsey, 'On Not Defining Sustainability' (2015) 18 Journal of Agricultural and Environmental Ethics 1075-1087.

15 On the specific role of courts in regulating broader risks through specific cases, see E.R. de Jong, 'Judicial Risk Regulation through Tort Law' (2018) 1 European Journal of Risk Regulation, 14-34.

16 See R. Pacheco-Vega, 'Environmental Regulation, Governance, and Policy Instruments, 20 Years after the Stick, Carrot, and Sermon Typology' (2020) 22(5) Journal of Environmental Policy and Planning 620-635.

17 See e.g. C. Sunstein, 'On the Expressive Function of Law' (1996) 144(5) University of Pennsylvania Law Review 2021-2053.

18 R. Thaler and C. Sunstein, Nudge: The Final Edition (Penguin, 2021).

19 See e.g. E. Beinhocker, 'Reflexivity, Complexity, and the Nature of Social Science' (2014) 20(4) Journal of Economic Methodology, 330-342.

20 J. van Zeben \& A. Rowell, Guide to EU Environmental Law (University of California Press, 2021), at 3 .

21 See e.g. B. van Rooij \& A. Fine, The Behavioral Code (Beacon Press, 2021).

22 van Zeben \& Rowell, supra n. 17, at 5.

23 See e.g. A. Gupta \& M. Mason (eds.) Transparency in global environmental governance: Critical perspectives (MIT Press, 2014).

24 This can be visited here: www.europarl.europa.eu/legislative-train/ (last accessed 19 October 2021). 
25 Explained here: https://ec.europa.eu/info/law/law-making-process/adopting-eu-law/implementing-and-delegated-acts/comitology_en\#: :text=Comitology $\% 20$ refers $\% 20$ to\%20a\%20set,say $\% 20$ in\%20the\%20implementing\%20acts (last visited 18 October 2021).

26 In the area of environmental law, see V. Heyvaert and L.-A. Duvic-Paoli, Research Handbook on Transnational Environmental Law (Edward Elgar, 2020).

27 District Court of The Hague, Milieudefensie et al. $v$ Royal Dutch Shell PLC (26 May 2021) C/09/571932/HA ZA 19-379.

28 C. Macchi \& J. van Zeben, 'Business and human rights implications of climate change litigation: Milieudefensie et al. $v$ Royal Dutch Shell' (2021) Review of European, Comparative \& International Environmental Law, doi:10.1111/reel.12416

29 Adapted from V. Ostrom, C. Tiebout, and R. Warren, "“The Organization of Government in Metropolitan Areas": A Theoretical Inquiry' (1961) 55(4) The American Political Science Review 831-842.

30 See J. van Zeben, 'Polycentric Features of the European Union' in J. van Zeben \& A. Bobić, Polycentricity in the European Union (Cambridge University Press, 2019) 28-50, at 28-31.

31 V. Ostrom, The Meaning of American Federalism: Constituting a Self-governing Society (ICS Press, 1994); M. McGinnis and E. Ostrom, 'Reflections on Vincent Ostrom, Public Administration, and Polycentricity' (2012) 72 Public Administration Review 1.

32 V. Ostrom, The Meaning of Democracy and the Vulnerability of Democracies: A Response to Tocqueville's Challenge (University of Michigan Press, 1997), 3-4.

33 See e.g. A. Lang, 'But Is It for Real? The British Columbia Citizens' Assembly as a Model of State-Sponsored Citizen Empowerment' (2007) 35(1) Politics \& Society 35-70; M. Gerber et al, 'Deliberative Abilities and Influence in a Transnational Deliberative Poll (EuroPolis)' (2018) 48(4) British Journal of Political Science 1093-1118.

34 Ostrom, supra n. 28, 199-221; M. Fotos, 'Vincent Ostrom's Revolutionary Science of Association' (2015) 163 (1) Public Choice 67-83.

35 This finding is in line with more general observations regarding the nature of climate law and policy design, which tends to favour actors with considerable socio-political power, see J. KnoxHayes, 'Negotiating Climate Legislation: Policy Path Dependence and Coalition Stabilization' (2012) 6(4) Regulation \& Governance 545-567.

36 T.W.G. van der Meer, 'Political Trust and the "Crisis of Democracy"' (2017) Oxford Research Encyclopedias, Politics, https://doi.org/10.1093/acrefore/9780190228637.013.77 (last accessed 18 October 2021).

37 R. Grant, 'Do Trees Talk to Each Other' (2018) Ask Smithsonian, available via www.smithsonianmag.com/science-nature/the-whispering-trees-180968084/ (last accessed 18 October 2021).

38 D. Kukovec, 'Peaceful Contestation', in van Zeben and Bobić, supra n. 27, 208-225, at 214.

39 See A. Honneth, Das Recht der Freiheit: Grundriss einer demokratischen Sittlichkeit (Suhrkamp, 2011).

40 F. Kroeger, 'The development, escalation and collapse of system trust: from the financial crisis to society at large' (2015) 33 European Management Journal 431.

41 On this, see also G. M. Genna, 'Images of Europeans: transnational trust and support for European integration' (2017) 20 Journal of International Relations and Development 358-380. 
42 See Opinion 2/13 [2014] EU:C:2014:2454 [191]; the Court emphasised the importance of that principle already in Joined cases C-411/10 and C-493/10, N.S. [2011] EU:C:2011:865 [83]: 'At issue here is the raison d'etre of the European Union and the creation of an area of freedom, security and justice and, in particular, the Common European Asylum System, based on mutual confidence and a presumption of compliance, by other Member States, with European Union law and, in particular, fundamental rights'; see further earlier judgments relying on a practically unrestricted principle of mutual trust, in Case C-305/05 Advocaten voor de Wereld [2007] EU:C:2007:383; Case C-396/11, Radu [2013] EU:C:2013:39; Case C-399/11 Melloni [2013] EU:C:2013:107.

43 In the context of the pandemic, see E. Brooks, A. de Ruijter, S. Greer, 'Covid-19 and European Union health policy: from crisis to collective action' in B. Vanhercke, S. Spasova \& B. Fronteddu (eds.) Social policy in the European Union: state of play 2020, Facing the pandemic (European Trade Union Institute and European Social Observatory, 2021).

44 A. Von Bogdandy, 'Ways to Frame the European Rule of Law: Rechtgemeinschaft, Trust, Revolution, and Kantian Peace' (2018) 14 European Law Review 675-699, at 691.

45 On deliberation in the face of climate change, see also L.-A. Duvic-Paoli, 'Re-imagining the Making of Climate Law and Policy in Citizens' Assemblies' Transnational Environmental Law (forthcoming 2021).

46 "Law for the Living Environment", Chair Plan LAW Group, 2021-2025, Wageningen University and Research, available at www.wur.nl/en/show/Law-for-the-Living-Environment-ChairPlan-2021-2025.htm (last accessed 18 October 2021).

47 See Amsterdam Institute for Advanced Metropolitan Solutions, www.ams-institute.org/ (last accessed 18 October 2021). See also short summary on the "Legal Navigation Map Circular Economy", https://drive.google.com/file/d/1JZQHnJUkctslJELZUY_DB7vq2QADIavq/view (last accessed 26 October 2021). 
32 I Prof.dr mr. Josephine A.W. van Zeben Law for the Living Environment 



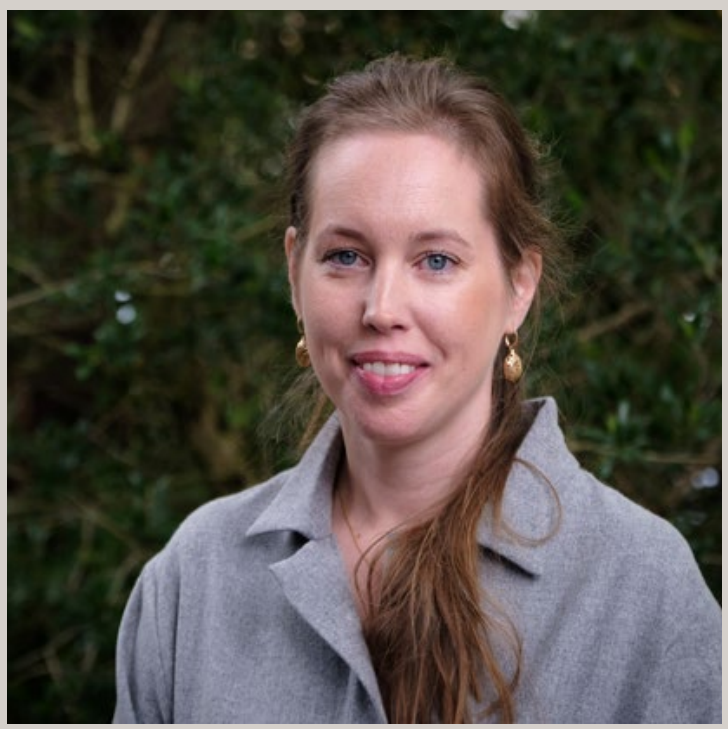

Prof.dr mr. Josephine A.W. van Zeben

"In this polycentric future, law should look to create more spaces for peaceful contestation. In this role, the law can help counter complexity through joint problem solving, and heal fragmentation through trust." 